\title{
我々国におけるメニエール病治療の動向
}

\author{
北嶋 和智・斎藤 春雄・北野 亿・北原 正章
}

\section{The Trend of Treatment in Ménière's Disease during the Past Ten Years}

\author{
Kazutomo Kitajima, Haruo Saito, Hitoshi Kitano and Masaaki Kitahara \\ (Shiga University of Medical Science)
}

\begin{abstract}
Medical and surgical treatment of Ménière's disease is controversial. Examining the questionnaires, one of the authors reported in 1970 on how otolaryngologists treat this disease in their daily practice. In 1980 the same questionnaires were sent to the otolaryngologists to find out changes in the treatment of Ménière's disease during the past ten years. The results are as follows: For the frequent attack of vertigo, injection of sodium bicarbonate (7\%) was more commonly used in 1980. Diuretics and steroid hormones were also more frequently used. For the remissional stage, internal medicines such as vasodilator, sedativa and $\beta$-histines were prescribed. In 1970 these three medicines were used almost with the same frequency, whereas in 1980 vasodilator was more frequently used than the other two. When it was noticed that the conservative treatment was ineffective, the next step was changing the prescription, consulting a neuro-otologist specializing in Ménière's disease or surgical management. In 1980 the frequency of consultation to the specialist was increased compared with 1970. Ineffectiveness of the first treatment was judged within 2 weeks in 1980, which was shorter than 4 weeks in 1970. Ás a final treatment of Ménière's disease, both conservative and surgical managements were taken into consideration. There was no change in the number of two managements between 1970 and 1980, suggesting the difficulty in the choice of final treatment. Although the amount of surgical management did not show any change, it was found that in 1980, the endolymphatic sac operation was more commonly selected, resulting in the decrease of choice for Rosen's operation and the operation destroying the labyrinth.
\end{abstract}

\section{緒言}

メニエール病に関しては, 薬剤治療, 食事療法, 安静物理療法, 手術的治療法等, 種々の方法が 発表されている，我々は1970年にそれらの治療法が実地臨床家にどのように評価され，利用されて いるかについて，日本耳鼻咽喉科学会会員を対象にアンケート調査を行った．以来今日までメ二エ 一ル病の病態に関しては種々の知見が報告され，また治療法にも多方面よりの検討が加えられてい る。そこで，今日におけるメニェール病に対する臨床医家の対処の仕方を知ると同時に，乙の10年 間のメニエール病治療の動向営知るために，1970年と同じ内容のアンケート調査を再度行い，この 
結果と，前回の結果を比較し，検討を加えたいと思う。

\section{調 查 方 法}

表 1 の如き，アンケート調査票を1970年 8 月 及び1980年 1 月に日本耳鼻咽喉科学会会員を対 象に発送した。会員名簿の各頁上段より, 各10 名づつ, 計 1200 名を対象とした. 名簿は, 調査 時の最新のものを用いているが，その対象構成 には大差はないと考えて良い。調査票発送時 に, 大学病院勤務医（以下大学と略する），病 院勤務員 (以下病院と略する), 診療所開設医 師（診療所と略する）の区別による数の調整は 行っていない. 回答は表 2 の如く, 204名(1970 年), 232名(1980年)から得られた。回答率はそ れぞれ17\%及び19.3\%である.1980年の方がや や多くの回答を得られたが, 大学, 病院, 診療

\section{表 1 アンケートの内容}

$$
\text { メニエール病治療回答 }
$$

〔1]激しいメマイ発作中にはどの様な薬物を投与さ れますか? 先生の頻用される薬剂名（処方）を 具体的に御記入下さい.

[2]屢々メマイ発作を繰り返す症例には発作の間歇 期にも薬物を投与されることがあると思いますが, この場合どの様な薬物を投与されますか? 先生 の頻用される薬剤名（処方）を具体的に御記入下 さい.

[3]薬物治療が無効の場合

イ）どの位の期間投与してみて一応無効と考えられ ますか？ 期間

口）そして次にどの様な治療をなさいますか？

[4]メニエール病のいわゆる最終的治療としては何 をされますか？またはどの様な治療がよいとお考 えですか?

成

急性期における処方を表 3 亿示す．全回答数 に対する割合を\%で示す，左側が1970年，右側 が1980年である．頻用されるものは，7\%重曹 水注射, $\beta$ - ヒスチン, 精神安定剂, 末梢血管 拡張剂, ビタミン剂内服, 制吐剂内服である. この時期に頻用される薬剤としては，10年間に 変化はないが，使用順位にやや変動がみられ る.すなわち1980年において，1970年と比較し
表 2 アンケート回答率

\begin{tabular}{|c|c|c|c|}
\hline 発 送 & & 回 & 率 \\
\hline \multirow{5}{*}{ 1200名 } & & 1970 年 & 1980 年 \\
\hline & & 204名 $(17.0 \%)$ & 232名 (19.3\%) \\
\hline & 大 学 & 29名 (14.2\%) & 35名 $(15.1 \%)$ \\
\hline & 病 院 & 42 名 (20.5\%) & 55名 (23.7\%) \\
\hline & 診療所 & 133名 (65.3\%) & 142名 $(61.2 \%)$ \\
\hline
\end{tabular}

所ごとの占める比率には差はない．

アンケートではメニエール病の治療を尋ねて いるが, メニエール病の Criteria は厳密に規 定はしていない。回答内容の理解と整理は, 次 の如く行った。すなおち, 調查票中〔 1 すめ まい発作中の治療であるが，〔2〕に関しては， 特に病期を指定せず，実際に間歇期にある症例 をいかに治療するかを問題とした。また回答に 処方(1)，処方(2)の様に 2 種類記載されている場 合は，重複している薬剤を除去し，両処方に使 われている薬剤は, 症例に応じ使用されてい ると考え，すべて採用した。調查票〔 3 】〔〔4] では回答内容を 1. 未記入，2．紹介又は重症 なし，3．手術治療，4. 保存的治療の 4 つに大 別し, 内容の重複している例では，より段階の 進んだ治療法を採用した。なお，〔3 〕，〔4〕 とも手術治療の経験の有無については問題とし なかった。

\section{績}

て減少したと考えて良いのは, $\beta$ - ヒスチン, ビタミン剂内服, 精神安定剂, 制吐剂（内服, 注射）である（P<0.05），逆に増加したもの は，末梢血管拡張剂 $(\mathrm{P}<0.01)$, 及び $7 \%$ 重曹 水注射 $(\mathrm{P}<0.05)$ である. 乙れ以外のものは10 年間に有意の差は認められなかった。末梢血管 拡張剤はこの10年を比較すると，1980年で dlisoproterenol, diphenidol が新たに加わって 
表 3 急性期における処方

\begin{tabular}{|c|c|c|}
\hline & 1970年: & 1980年 \\
\hline 1. 内 服 & & \\
\hline$\beta$ - ヒスチン & $41.6 \%$ & $31.9 \%$ \\
\hline 精神安定剂 & $41.6 \%$ & $31.9 \%$ \\
\hline 末梢血管拡張剂 & $37.7 \%$ & $56.9 \%$ \\
\hline ビタミン剂 & $26.9 \%$ & $18.5 \%$ \\
\hline 制 吐 剂 & $24.1 \%$ & $16.4 \%$ \\
\hline そ の 他 & $20.0 \%$ & $21.6 \%$ \\
\hline 2. 注 射 & & \\
\hline $7 \%$ 重曹水 & $63.7 \%$ & $73.3 \%$ \\
\hline 制 吐 剂 & $21.0 \%$ & $6.9 \%$ \\
\hline ビタミン剂 & $14.2 \%$ & $10.8 \%$ \\
\hline 鎮 静 剂 & $7.3 \%$ & $11.2 \%$ \\
\hline 補液 & $5.8 \%$ & $3.0 \%$ \\
\hline その 他 & $11.2 \%$ & $14.2 \%$ \\
\hline 3. 物理療法等 & $5.3 \%$ & $2.6 \%$ \\
\hline 4. 未記入 & $2.4 \%$ & $1.7 \%$ \\
\hline
\end{tabular}

いる．乙の 2 者は末梢血管拡張剂の $59 \%$ を占め ているが，1980年の末梢血管拡張剂の 增加及 び， $\beta$ - ヒスチン，ビタミン剤内服の減少と大 い関係があると考えられる．急性期の処方中 における，その他の薬剈の内容を実数（人）で 表 4 亿示す．利尿剂，ステロイド剂，代謝促進 剤, 抗ヒスタミン剤, 自律神経薬剤, 循環治療 剂，脳代謝改善剂等があるが，70年と80年で特

表 4 急性期におけるその他の内容

\begin{tabular}{|c|c|c|}
\hline & 1970年 & 1980年 \\
\hline 1. 内 服 & & \\
\hline 利尿 郕 & 4 人 & 5 人 \\
\hline ステロイド & 9 人 & 19 人 \\
\hline 代謝促進剤 & 16 人 & 10 人 \\
\hline 抗ヒスタミン剂 & 8 人 & 3 人 \\
\hline 自律神経治療剂 & - & 4 人 \\
\hline 脳代謝改善剂 & - & 3 人 \\
\hline 循環治療剂 & 4 人 & 8 人 \\
\hline 2. 注 & & \\
\hline ステロイド & 4 人 & 17 人 \\
\hline 代謝促進剂 & 5 人 & 11 人 \\
\hline 抗ヒスタミン剂 & 2 人 & 5 人 \\
\hline
\end{tabular}

に目立った変化は認められない，但しステロイ ド剂については, 内服, 注射とも増加している. 表 5 に, 物理療法, Stellate Block（SB）の内

表 5 急性期における物理療法等

\begin{tabular}{|c|c|c|}
\hline & 1970年 & 1980年 \\
\hline 食事療 法 & 3 人 & 1 人 \\
\hline 安 & 3 人 & 2 人 \\
\hline 針 治 療 & - & 1 人 \\
\hline 酒 & 1 人 & 1 人 \\
\hline $\mathrm{S} B$ & 5 人 & 2 人 \\
\hline 炎 & - & 1 人 \\
\hline
\end{tabular}

容を実数で示す。食事療法, 安静, 酒, SB が, 70年 80 年に 共通して 認められる。 80 年に針治 療，炎治療がみられる以外，特に新しい所見は ない。

間歇期における治療法を表 6 亿示す。急性期

表 6 間歇期における処方

\begin{tabular}{c|c|c}
\hline & 1970 年 & 1980 年 \\
\hline 1. 内 服 & & \\
末梢血管拡張剂 & $61.2 \%$ & $83.6 \%$ \\
ビタミン郕 & $59.8 \%$ & $42.2 \%$ \\
精神安定剂 & $58.8 \%$ & $45.3 \%$ \\
$\beta$ - ヒスチン & $57.3 \%$ & $35.3 \%$ \\
自律神経治療剂 & $14.2 \%$ & $15.5 \%$ \\
そ の 他 & $26.9 \%$ & $26.3 \%$ \\
2. 注 射 & & \\
7\%重曹水 & $10.2 \%$ & $3.0 \%$ \\
その 他 & $7.3 \%$ & $1.7 \%$ \\
3. 物理療法等 & $3.7 \%$ & $1.7 \%$ \\
4. 未 記 入 & $2.9 \%$ & $2.6 \%$
\end{tabular}

における治療と同様に，70年と 80 年を比較して みると增加している薬剤は, 末梢血管抎張凨で あり $(\mathrm{P}<0.01)$ ，逆に減少しているものは， ビタミン鼡, 精神安定剤, $\beta$ - ヒスチンである $(\mathrm{P}<0.01)$. 80年の末梢血管拡張剂 $84 \%$ の内訳 けで43\%は，先ほどのい゙た dl-isoproterenol 及 び diphenidol の 2 者であるので， この時期に 
はこれらの薬剂が頻用されていることが判る. 他の薬剤が70年に比して減少しているのもての ためではないかと考えられる。自律神経剤は， 70年, 80年とも数は少いが, 変動はあまりなく, underlying condition への配慮がうかがえる. この時期には注射療法は少ない. $7 \%$ 重曹水, ビタミン剂の注射等が時に行なわれる程度であ る. 表 7 亿間歇期における, その他, 物理療法, SB の内容を実数で示す. 急性期（表 4) 亿比 べて, 代謝促進剤, 循環治療剂が増加して, や はり underlying condition の改善が画られて いる. 70 年と 80 年では特に目立った変化はな い.

次に，薬剤無効例に対する処置は如何なるも のかを調査票〔 3 ]で見る．回答内容を 1 ．未記 入 2. 紹介, 重症なし, 3. 手術治療, 4. 保 存的治療の 4 項目に分けてそれぞれの頻度をみ る. 表 8 にその結果を示す。総計では70年, 80
表 7 間歇期における, その他, 物理療法, $\mathrm{SB}$ の内容

\begin{tabular}{|c|c|c|}
\hline & 1970年 & 1980年 \\
\hline \\
\hline 代謝促進剤 & 25 人 & 48 人 \\
\hline 循環治療剤 & 14 人 & 20 人 \\
\hline 脳代謝改善剂 & - & 11 人 \\
\hline 利 尿 剂 & 2 人 & - \\
\hline ステロイド剤 & 2 人 & 2 人 \\
\hline \multicolumn{3}{|l|}{ 2. 物理療法等 } \\
\hline 事 & 1 人 & 2 人 \\
\hline 酒 & 1 人 & 1 人 \\
\hline 安静, 生活指導 & - & 1 人 \\
\hline S B & 1 人 & - \\
\hline
\end{tabular}

年とも, 保存的治療, 紹介重症なし, 手術の順 で多い. 大学, 病院, 診療所の 3 群別にみると, 大学では, 両年代共に, 手術治療が紹介重症な しを上回っている. 他の 2 群は総計と同じ順で

表 8 薬物療法無効例の処置

\begin{tabular}{l|rl|rr|rr|rr}
\hline \hline & 総 & 計 & 大 & 学 & 病 & 院 & \multicolumn{2}{|c}{ 診 療 所 } \\
\hline & 1970 年 & 1980 年 & 1970 年 & 1980 年 & 1970 年 & 1980 年 & 1970 年 & 1980 年 \\
1. 未記 入 & $10.7 \%$ & $10.8 \%$ & $6.8 \%$ & $5.7 \%$ & $4.7 \%$ & $3.6 \%$ & $13.5 \%$ & $14.8 \%$ \\
2. 紹介, 重症なし & $19.5 \%$ & $31.5 \%$ & $3.4 \%$ & $14.3 \%$ & $16.8 \%$ & $23.6 \%$ & $23.2 \%$ & $38.7 \%$ \\
3. 手術 治 療 & $10.2 \%$ & $10.3 \%$ & $24.1 \%$ & $28.6 \%$ & $16.6 \%$ & $18.2 \%$ & $4.5 \%$ & $2.8 \%$ \\
4. 保存的治療 & $64.7 \%$ & $47.4 \%$ & $61.9 \%$ & $51.4 \%$ & $59.3 \%$ & $54.5 \%$ & $58.5 \%$ & $43.7 \%$
\end{tabular}

ある. 70 年と 80 年の双方を比較すると， 80 年で 増加しているものは，紹介重症なし，である。 $(\mathrm{P}<0.01)$. 乙の項を 3 群別にみると, 診療所 での増加が有意である $(\mathrm{P}<0.01)$ ，逆に減少を 示したのは，保存的治療である $(\mathrm{P}<0.01)$ 。乙 の項を各群別にみると, 骖療所での減少が有意 である $(\mathrm{P}<0.01)$. 手術治療については，70年 と80年で変化はみられない，全体としてみる と, 診療所の対応すなわち, ある時期で保存療 法を切り上げ，大学又は病院へ紹介する事が 80 年においてより明確になって来たと考えて良 い. この診療所での変化が総計に反映されて来 たと云える.
手術治療の内谷を表 9 亿示す。70年に最も多 かった鼓索神経切断術が80年では逆に最も少な くなっている。ポルトマン氏手術に代表される 内リンパ霅減荷術が增加している。

保存療法の内容を表10 亿示す. 安静食事療 法, SB, 薬剤治療の 3 項目に分けてその頻度 をみる．70年と 80 年の比較で増加しているもの

表 9 手術治療の内容

\begin{tabular}{|c|c|c|c|}
\hline & 1970年 & \multicolumn{2}{|c|}{ 1980年 } \\
\hline 鼓索神経切断術 & 10 名 & 3 & 名 \\
\hline 内リンパ囊減荷術 & 4 名 & 7 & 名 \\
\hline 不 明 & 6 名 & 13 & 名 \\
\hline
\end{tabular}


表10 薬物無効例に対する保存的治療の内容

\begin{tabular}{l|rr|rr|rr|rr}
\hline & 総 & 計 & 大 & 学 & \multicolumn{2}{|c|}{ 病 } & 院 & \multicolumn{2}{|c}{ 診 療 所 } \\
\hline & 1970 年 & 1980 年 & 1970 年 & 1980 年 & 1970 年 & 1980 年 & 1970 年 & 1980 年 \\
1. 安静食事療法 & $17.6 \%$ & $14.2 \%$ & $17.2 \%$ & $25.7 \%$ & $14.2 \%$ & $7.2 \%$ & $18.0 \%$ & $14.1 \%$ \\
2. S B & $19.1 \%$ & $7.9 \%$ & $25.7 \%$ & $5.7 \%$ & $26.1 \%$ & $5.5 \%$ & $15.0 \%$ & $9.2 \%$ \\
3. 薬剂治療 & $23.0 \%$ & $33.6 \%$ & $17.2 \%$ & $40.0 \%$ & $19.0 \%$ & $49.1 \%$ & $25.5 \%$ & $26.1 \%$
\end{tabular}

は薬剤治療である $(\mathrm{P}<0.01)$ ，逆に減少を示し ているものは SB である $(\mathrm{P}<0.01)$. SB は 80年において，むしろまれにしか行なわれてい ないと云える。安静食事療法は70年と80年で変 動はなく，発症要因に 対する配慮が認められ る。 その具体的な内容は, 精神療法, 生活指導 食事指導(減塩食), 針治療, 良導絡療法等であ る. 70 年と 80 年で大きな変動はない.

薬剂治療が無効の時, 次の治療法に移行する 時期及びその内容を図 1 亿示す。縦軸が回答 数, 横軸が時期（週単位）である。次に選ぶ治 療内容により 3 群に分ける。すなわち，・印は
さらに保存治療を考える場合， $\triangle$ 印は専門医へ 紹介する場合，×印は手術治療を考える場合で ある，図中左側は1970年，右側は1980年である. 両年代とも多くは 4 週間以内に次の治療法を考 えている。すなわち70年で64\%，80年で69\%を 占める。但し, 次の治療法を選ぶ際に，70年で は特に目立ったピークはないが，80年では 2 週 目にピークがある。また，次に手術治療を考え る時期は70年では特徴的な所見はないが，80年 では12週をすぎてから考える人が $79 \%$ 占めて いる。 またての時期においては，手術療法を選 択する人が保存的療法又は紹介より多く，70年
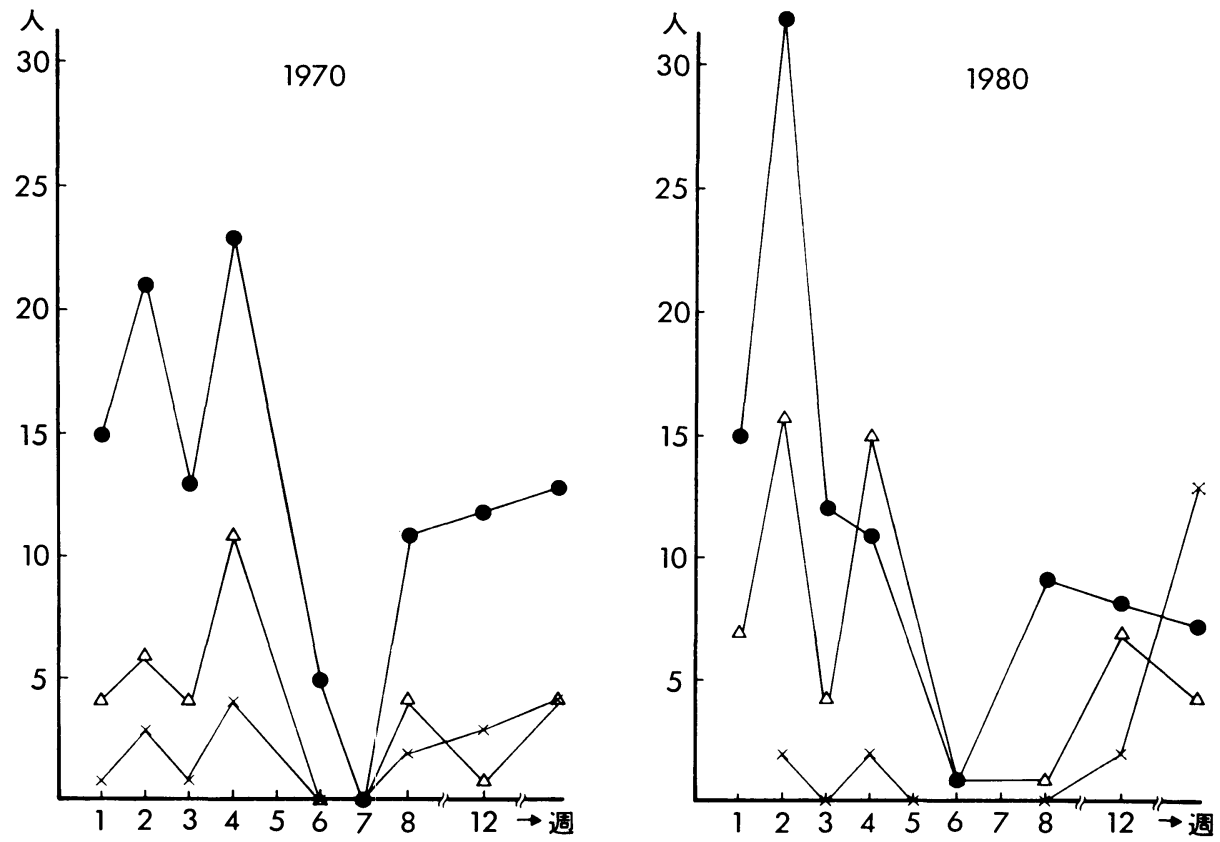

○保存的治療 $\triangle$ 尃門医紹介 $\times$ 手術治痖

図 1 
に比して逆の所見を示したのが特徵的である. 全体としてみると，80年は70年に比して一つの 傾向が明らかになっている，すなわち，まず 2 週間を予定に保存的治療がはじめられ，投薬内 容を変更したり，あるいは紹介も考えながら対
処され，12週を過ぎると，手術的療法が考えら れると云える.

設問〔4〕については,〔3]と同様の分類を 行った. 表11にその結果を示す. 70年80年とで は, 各項目とも, 総計及び, 大学病院, 診療所

表11 最終治療の内容

\begin{tabular}{l|rr|rr|rr|rr}
\hline & 総 & 計 & 大 & 学 & 病 & 院 & \multicolumn{2}{|c}{ 診 療 所 } \\
\hline & 1970 年 & 1980 年 & 1970 年 & 1980 年 & 1970 年 & 1980 年 & 1970 年 & 1980 年 \\
1. 未記入 & $21.0 \%$ & $18.5 \%$ & $13.7 \%$ & - & $11.9 \%$ & $18.2 \%$ & $22.5 \%$ & $23.2 \%$ \\
2. 紹介, 重症なし & $8.2 \%$ & $4.3 \%$ & - & - & $4.9 \%$ & $3.6 \%$ & $11.1 \%$ & $5.6 \%$ \\
3. 手術治療 & $31.8 \%$ & $37.1 \%$ & $69.0 \%$ & $71.4 \%$ & $52.3 \%$ & $40.0 \%$ & $18.7 \%$ & $27.5 \%$ \\
4. 保存的治療 & $38.5 \%$ & $40.0 \%$ & $24.1 \%$ & $28.6 \%$ & $30.9 \%$ & $38.2 \%$ & $44.3 \%$ & $43.7 \%$
\end{tabular}

の 3 群別においても，有意の変化はみられな い.〔4]では, メニエール病の最終治療に対す る各臨床医家の既念と云ったものを知る事が出 来る。乙れに対し，〔3〕は対処の実際的方法を 問うているので，〔3]と[4]の比較，変動の様
子は，治療の方向あるいは期待を知る一つの目 安とする事が出来る. 図 2 亿総計での比較を示 す．中心より左側に[3]の，右側に〔 4$]$ 回答 内容を示す。水平方向の棒グラフで頻度 $(\%)$ を 示す。上段が70年，下段が80年である．両年と

1970年

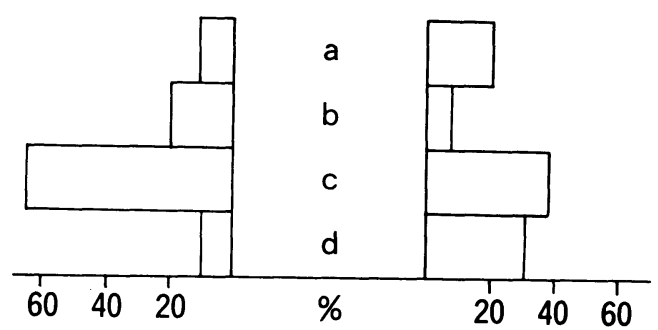

1980年

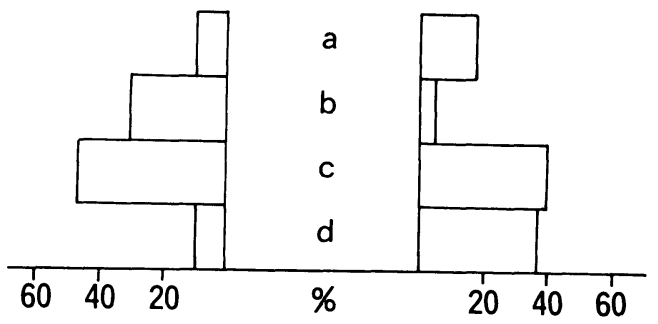

$a ：$ 末記入 b：紹介, 重症なし 
も，〔4]で保存的治療が減少し，未記入，手術 治療が増加している。〔3 〕で頻度の高かった保 存的治療の人が，最終治療として如何なる態度 をとったかを表12に示す．70年，80年とも，半 数近くの人がなお保存的治療をとり, 約 $1 / 3$ の 人は手術治療を選択している。四 3 は, 大学, 病院, 診療所別の変化を示す. 70 年80年とも同
表12〔3〕において保存的治療とした人の 最終治療での選択

\begin{tabular}{l|r|r|r|r}
\hline \hline & 未記入 & $\begin{array}{l}\text { 紹介, } \\
\text { 重症なし }\end{array}$ & 手術治療 & 保存的治療 \\
\hline 1970年 & $16.5 \%$ & $12.4 \%$ & $28.0 \%$ & $43.1 \%$ \\
1980年 & $15.4 \%$ & $1.9 \%$ & $33.5 \%$ & $49.2 \%$
\end{tabular}

1970年
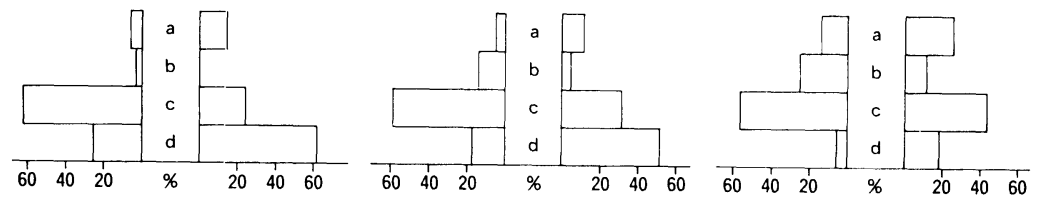

1980年
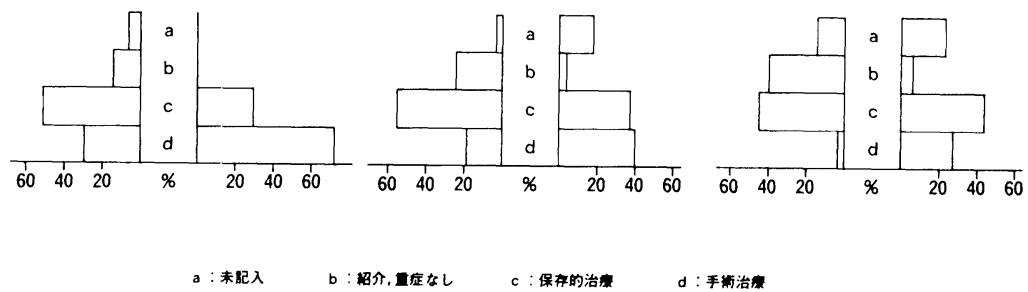

b：绍介、置症なし

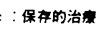

図 3

じ動向にある。すなわち，大学，病院，診療所 いずれの群においても保存的治療は減少し，手 術治療は増加している。 大学と病院では, 手術 治療の方が保存的治療より頻度が高くなってい るが，誩療所ではなお保存的治療が優位であ る。では最終治療における保存的治療及び手術 療法の内容をのべる. 表13に保存的治療の内容 を示す。70年80年ともに，安静食事療法，薬剤
治療，SB である．70年には各群に SB が散見 されるのであるが80年には診療所群で 1 名あっ たのみである．他には70年と 80 年で大きな変化 は認められない。安静食事療法の内容は, 精神 療法及び生活指導, 自律神経安定, 減塩食等で あるが，東洋医学として，70年に良導絡療法 3 名，80年に針治療 4 名と，少ないながらもての 10年ある率を占めているのは興味深い。

表13 最終治療での保存的治療の内容

\begin{tabular}{l|rr|rr|rr|r|r}
\hline & 総 & 計 & 大 & 学 & 病 & 院 & \multicolumn{2}{|c|}{ 診療 所 } \\
\hline & 1970 年 & 1980 年 & 1970 年 & 1980 年 & 1970 年 & 1980 年 & 1970 年 & 1980 年 \\
安静食事療法 & $20.0 \%$ & $22.0 \%$ & $17.2 \%$ & $14.3 \%$ & $16.6 \%$ & $14.5 \%$ & $21.8 \%$ & $26.8 \%$ \\
S B & $6.3 \%$ & $0.4 \%$ & $3.4 \%$ & - & $4.6 \%$ & - & $7.5 \%$ & $0.7 \%$ \\
薬剂治療 & $12.2 \%$ & $24.1 \%$ & $3.4 \%$ & $20.0 \%$ & $4.9 \%$ & $29.1 \%$ & $15.0 \%$ & $23.2 \%$
\end{tabular}


手術治療の内容を表14に示す。内耳の一部又 は全部破壞手術としては，迷路摘出，超音波照 射, 凍結手術, Lempert 氏手術, Dandy 氏手 術等があり, 減荷手術としては, Portmann 氏 手術及びその変法がある。その他とは内容の不 明であったものを指す。70年と 80 年を比較する と，70年には最も少なかった減荷手術が80年に 最も多くなったととが顕著な変化と云える，逆 に迷路破壊は減少し，鼓索神経切断はむしろま れなとととなっている（いずれも $\mathrm{P}<0.01 ）$.

以上の統計的処理とは別にして，回答につい て目にとまったのは[2]，〔3]の設問に対して 「大学又は大病院に紹介するが，自分の治療内
表14 最終治療での手術治療の内容

\begin{tabular}{|c|c|c|}
\hline 手 術 法 & 1970年 & 1980年 \\
\hline 全部又は一部迷路破壞 & $40.6 \%$ & $23.2 \%$ \\
\hline 内リンパ顀減荷手術 & $16.3 \%$ & $36.0 \%$ \\
\hline 跂索神経切断術 & $20.9 \%$ & $5.8 \%$ \\
\hline そ の 他 & $22.1 \%$ & $34.9 \%$ \\
\hline
\end{tabular}

容と大差はない」との回答や，〔4〕の設問に対 して「本態不明の病気に適切な治療はない」と の回答がみられたてとである。このような具体 的な意見をのべた人は小数であるが，メニェー ル病治療に対する率直で，しかも示唆にとんだ 意見だと思う。

\section{総 括, 考 按}

メニエール病の治療は, 古くから薬物, 手術 治療の他, 食事療法, 物理療法など多彩である。 また治療の種類内容も変遷が大きい。これらの 治療法がこの10年間に，実地臨床医家によって 如何なる評価を受けて来たかをての調査で知る ことが出来た。 また多彩の中にも一つの動向を 見出すことが出来た。

以下 1980 年の結果を1970年のものと比較しな がら具体的にのべる．急性期の治療はやはりめ まい嘔気の除去がまず第一と考えられる．7\% 重曹水の注射が73\%に行なわれており，10年前 の69\%よりさらに増加している。本剤のめまい に対する即効性がさらに認識される。内服不能 の場合は，鎮静剤(11\%)，ステロイド剂( $7 \%$ ) の注射も行なわれる.内服で最もよく使用され るのは末梢血管拡張剤 (57\%)であり，てのうち 約半数は dl-isoproterenol, diphenidol の 2 者 である．70年の調査では， $\beta$ - ヒスチン $(42 \%)$, 精神安定剂 (42\%)，血管拡張剂 (38\%)の 3 者が 頻用され，特にこれら 3 者間に差はなかったの であるが，80年では末梢血管拡張剂の増加が特 徵的である. dl-isoproterenol, diphenidol は それぞれ1976年，1974年から一般臨床使用がな されており，乙れらの薬物が以後頻用されてい る状況が反映されている，80年においては，7
\%重曹水の注射，血管拡張剤の内服と云う様 に，70年に比してより定形的にはなって来てい るが，一方で利尿剂，ステロイド剤の使用は増 加しており，とくに難聴に対する配慮とうけて とれる。

間歇期の処方は発作の再発防止，残遺症状の 除去が主目的である。注射よりは内服が主体と なる．70年では末梢血管拡張剂，ビタミン剂， 精神安定剂， $\boldsymbol{\beta}$ - ヒスチンの 4 者が上位を占 め，いずれも60\%前後であった８0年ではてれ ら 4 者のうち, 末梢血管拡張剤が $84 \%$ と增加 し, 他の 3 者は減少を示した。末梢血管拡張剂 の約半数は先にの心゙た。 dl-isoproterenol, diphenidol である。乙の時期には，急性期に 比して, 自律神経治療剂, 代謝促進剤等の頻度 が増加しており，70年と80年の間では変動はな い. メニエール病の underlying condition に 対する配慮がうかがえる。

薬物療法が無効である場合に，次におてなわ れることは，(1)処方内容を変更してさらに薬物 療法をつづける。(2)他の施設を紹介する。(3)手 術治療を考えるの 3 者が主なものである. 総 計, 病院, 診療所では (1), (2), (3)の順に頻度 が高い，大学で法，(3)の手術療法が(2)の紹介を 上回っている。乙れらの所見は70年，80年とも 
にみられることである。乙の10年の動向をみる と, 紹介の項が大学, 病院, 䛦療所ともに増加 しており，専門分化の傾向が反映されている. また診療所群での保存的治療の頻度もむしろ少 なくなって来ており, てのぶん, 大学や病院へ の紹介が増えているものと考えられる.

薬物治療が無効時に次の治療法に移行する時 期であるが, 70年では $64 \%, 80$ 年では $69 \%$ の人か 1 ヶ月以内に次の処置を決定している。但し70 年ではこの 1 ヶ月の間に特にピークはみられな かったのに対し，80年では 2 週目にピークがあ り, 治療法変更の決定がより早く行なわれる様 になった。また70年の調査では，手術治療に移 る時期には特にピークがなく，手術時期決定の 困難さがうかがえたが，80年に抢いては，79\% の人が 3 ヶ月を過ぎてから決定堂下しており， 手術決定の時期がより明らかに䄈っている.

最終治療として如何なる方法を考えているか については，表11で示した様に，未記入，手術 治療, 保存的治療の 3 者ともか极りの頻度を占 め，70年，80年とも大きな変化はない，10年の 経過を経てもなお，最終治療法潠択の困難さは
解消されていない.しかし手術治療の具体的内 容に関しては，80年においては，10年前に比 し, 鼓索神経切断術は激減し，また厳密な適応 を要求される迷路破壊術も減少を示し, 逆に, より広い適応を持ち，生理的手術である内リン パ囊減荷術が増加している。乙のことは，手術 法選択に関し，乙の10年間に，聴覚に対する配 慮さらには，より効果的な手術法についての考 慮がなされて来ているととの証左と云える。ま た先にのべた様に，保存的治療の内容，治療方 針変更の時期等についてもとの10年間に一定の 動向がみられることから，より明確な治療方針 への着実な歩みを知ることが出来る。しかしな がら, 実地臨床医として, 確たる治療方法を求 めての不満のあることも拣実である，具体的 に意見をのべた人は少数ではあったが，乙の種 の不満は多少とも，各臨床家に共通のものと考 えられる.このためにてそ，臨床医学でメ二エ 一ル病をとり上げる限り, その研究目標は治療 につながるものでなければならない事を痛感さ せられた。

語

メニエール病の具体的な治療方法に関して，1970年と1980年に，同じ内容のアンケート調査を行 った．対象は日本耳鼻咽喉科学会会員である．その結果この10年間の治療動向を知ることが出来た. 結果を以下に示す．発作の頻発する急性期には，7\%重曹水の注射がより多く使われる様になった。 数は少ないが利尿剤やステロイド剂も増加を示している．間歇期には，末梢血管拡張剤，精神安定 剤， $\beta$ - ヒスチンの 3 者がよく使用されるのであるが，1970年では， 3 者とも同じ頻度であった。 1980年においては， 3 者のうち，末梢血管挔張剂が著明に増加した。

保存的治療が無効と考光られると, 次にとられる治療法は, 処法の変更, 専門医への紹介, 手術 治療の 3 者である. 1970年と1980年を比較すると，専門医への紹介が増加しているのが特徵的であ った．初期治療が無効であると判定される時期は1980年では 2 週間であり，1970年の 4 週間と比較 すると，ての判定がより早くなっている。メニェール病の最終治療として，1970年，1980年の双方 とも保存的治療，手術的治療の 2 者があげられており，10年間での変動はない。このととは最終治 療法の選択のむずかしさをそのまま反映している，但し手術治療の内容に関しては，1980年に内リ ンパ囊手術が増加し，1970年に多かった，迷路破壊手術，鼓索神経切断術は著明に減少を示してい る.

$$
\text { メニェール病の治療法はな打多彩ではあるが, この10年間に一つの傾向をみるととが出来た。 }
$$


本論文の要旨は, 第82回日本耳鼻咽堠科学会総会宿題報告 “メニエール病の基礎と臨床” の一部として報告し た. この調査に後協力下された先生方に厚く御礼申し上げます.

\section{参 考 文 献}

1）菊地尚子：メニエール病の治療に関する研究. 耳 鼻 $24: 640 \sim 655,1978$.

2) 北原正章：メニエール 病手術の適応. 耳鼻臨床 $67: 1171 \sim 1173,1974$.

3 ) 北原正章, 岸本誠司, 松原秀春：心身医学的にみ たメニエール病. 耳鼻臨床 $70: 1778 \sim 1882,19$ 77.

4) 水越鉄理, 他 : 厚生省特定疾患入ニエール病調査 研究班によるメニエール病の疫学調査と症状調査 （個人調查票・症状調査票による集計と対照例と の比較). 耳鼻臨床 $70: 1669 \sim 1686,1977$.
5 ）渡辺勈：メニエール病, 1.治療計画の基礎. 日耳 鼻 $80: 974 \sim 978,1977$.

6 ）八木伸也, 北原正章 : 我国におけるメニエール病 治療の現況. 耳鼻臨床 $65: 923 \sim 930,1972$.

7 ) 山崎勤, 渡辺幸枝, 小崎秀夫, 阿部隆夫, 山本一 男, 柳川統, 酒井昇, 山川宗位, 松島純一: アン ケート調査からみたメニエール病患者の治療法の 検討. 耳鼻臨床 73 ：増 $2 ； 1134 \sim 1141 ， 1980$.

$$
\left(\begin{array}{l}
\text { 別刷請求先 }: \text { 北嶋 和智 } \\
\bar{\top} 520-21 \text { 大津市瀬田月輪町 } \\
\text { 滋賀医科大学耳鼻咽喉科学教室 }
\end{array}\right)
$$

